\title{
МУЛЬТИКОМПОНЕНТНЫЙ СИНТЕЗ И МЕХАНИЗМ ОБРАЗОВАНИЯ ПОЛИЗАМЕЩЕННЫХ 1,4,5,6 ТЕТРАГИДРОПИРИДИНОВ
}

\author{
Т.М. Илиясов, А.Н. Верещагин \\ Институт органической химии им. Н.Д. Зелинского РАН \\ 119991, г. Москва, Ленинский пр., 47.
}

DOI: 10.19163/MedChemRussia2021-2021-422

E-mail:nfsmwm5@mail.ru

Одними из наиболее распространенных биоактивных соединении являются гетероциклы азота [1]. В частности производные тетрагидропиридины и пиперидины широко распространены в природных моноциклических и бициклических алкалоидах и синтетических лекарствах[2], которые обладают широким спектром фармакологической и биологической активностью [3] [4].

Был осуществлен четырёхкомпонентный синтез полизамещенных 1,4,5,6 тетрагидропиридинов 4. Был установлен механизм данной реакции. Процесс представляет собой последовательность реакции: присоединение по Михаэлю реакция Манниха - внутримолекулярная циклизация с образованием соединения A - дегидратация с образованием 3,4,5,6 тетрагидропирина В с последующей таутомеризацией в конечный продукт 4.
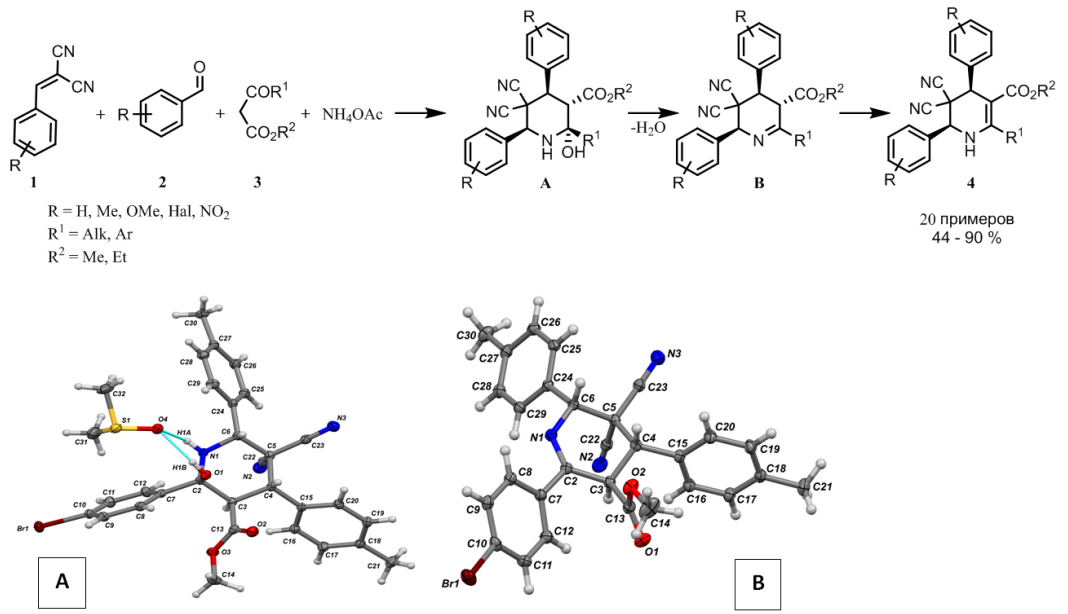

Литература

[1] Vitaku, E.; Smith, D. T.; Njardarson, J. T. Journal of Medicinal Chemistry 2014, 57, (24), 10257-10274.

[2] Watson, P. S.; Jiang, B.; Scott, B. Organic Letters 2000, 2, (23), 3679-3681.

[3] O’Hagan, D. Natural Product Reports 2000, 17, (5), 435-446.

[4] Natsume, M.; Ogawa, M. Chemical and Pharmaceutical Bulletin, 1984, 32, (9), 3789-3791 